\title{
SABRiBEY Maltlık Arpa Çeşidinin Islah Hikayesi
}

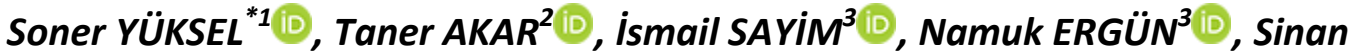

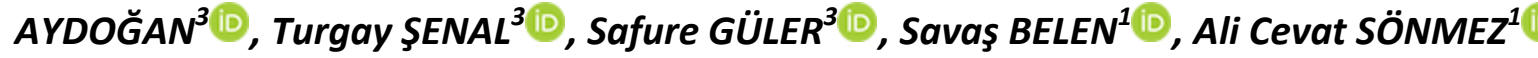

\author{
${ }^{1}$ Geçit Kuşağı Tarımsal Araştırma Enstitüsü Müdürlüğü / Eskişehir \\ ${ }^{2}$ Akdeniz Üniversitesi Ziraat Fakültesi Tarla Bitkileri Bölümü / Antalya \\ ${ }^{3}$ Tarla Bitkileri Merkez Araştırma Enstitüsü Müdürlüğü / Ankara
}

Öz: Arpanın geniş alanlarda yetiştirildiği Orta Anadolu Bölgesi için maltlık kalitesi yüksek yeni çeşitlerin üretim alanlarına hızla girmesi ülke tarımına katma değer katacaktır. Arpa çeşit geliştirme çalışmaları kapsamında yapılan bir melezlemede CWB117-5-9-5/ST5819 hattı ile Kalaycı-97 çeşidinin iyi özelliklerinin bir çeşitte toplanması amaçlanmıştır. Anılan melez 1999 yılında F1 generasyonu, 2000-2003 yılları arasında açılan kademe materyali ve 2004 yılında gözlem bahçesi olarak denemeye alınmıştır. 2005 yılında ön verim ve 2006 yılında verim denemesine seçilmiştir. 2007 ve 2008 yılların da verim denemesi kademesinde yer alarak Eskişehir Karabayır lokasyonunda denenmiş ve ilk yıl 675 kg/da verim ile ilk sırada ikinci yıl ise $638 \mathrm{~kg} / \mathrm{da}$ verim ile dördüncü sırada yer almıştır. Kışık, iki sıralı ve yatmaya dayanıklı olan Sabribey çeşidi, verim ve kalite değerleri dikkate alınarak 2019 yılında maltık arpa çeşidi olarak tescil edilmiştir. Sabribey arpa çeşidinin önemli özelliklerinden hektolitre ağılığı 64.3-74.1 kg/hl, bin tane ağılığı 30.8-31.9 g, tanede nişasta \%60.9-64.9, tanede protein \%9.4-13.9, 2.5+2.8 mm elek üstü \%45.2-88.4, elek altı \%2.4-5.0, irilik sınıfı 3-8, kavuz oranı \%9.5-10.2, friabilite değeri \%51.9-85.4, ince ekstrakt \%75.2-78.9, hartong sayısı \%35.7-37.0, kolbach sayısı \%57.6-102 arasında değişmektedir.

Anahtar kelimeler: Tescil, sertifikasyon, melezleme, generasyon

\section{Breeding Story of Malting Barley Variety Sabribey}

\begin{abstract}
For the Central Anatolia Region, where barley is grown in large areas, the rapid introduction of new varieties with high malting quality into the production areas will add added value to the country's agriculture. In a crossing made within the scope of barley cultivar development studies, it was aimed to collect the good characteristics of CWB117-5-9-5/ST5819 line and Kalayc1-97 cultivar in one cultivar. The aforementioned hybrid was put into trial as F1 generation in 1999, segregated material between 2000-2003 and observation nursery in 2004. It was selected for pre-yield trial in 2005 and yield trial in 2006. It was tested in Eskişehir Karabayır location by taking part in the yield trial stage in 2007 and 2008. The material ranked first with a yield of $675 \mathrm{~kg} / \mathrm{da}$ in 2017 and fourth place with a yield of $638 \mathrm{~kg} / \mathrm{da}$ in 2008. The Sabribey variety, which is wintertype, two-row and resistant to lodging, was registered as malting barley variety in 2019, taking into account its yield and quality values. The important features of Sabribey barley variety are $64.3-74.1 \mathrm{~kg} / \mathrm{hl}$ hectoliter weight, 30.8-31.9 g per thousand grain weight, grain starch 60.9-64.9\%, grain protein 9.4-13.9\%, 2.5+2.8 mm sieve 45.2-88.4\%, under sieve $2.4-5.0 \%$, size class 3-8, husk ratio 9.5-10.2\%, friability value 51.9-85.4\%, fine extract 75.2-78.9\%, Hartong number 35.7-37.0\%, kolbach number 57.6-102\%.
\end{abstract}

Keywords: Registration, certification, hybridization, generation

\section{Giriş}

Arpa (Hordeum vulgare L.), ilk kültüre alınan bitkilerden birisidir Smith ve Nesbitt (1995). Mezopotamya ve Mısır'da yapılan arkeolojik çalışmalarda daha fazla arpa kalıntılarının tespit edilmesi insan beslenmesi açısından arpanın buğdaydan daha fazla kullanılmış olabileceğini göstermektedir (Ceccarelli ve ark., 2007). ilk zamanlar insan beslenmesinde kullanılan arpa, zaman geçtikçe buğday ve çeltik gibi bitkilerin öne çıkmasıyla hayvan yemi olarak tüketimi artmıştır (Baik ve Ullrich., 2008). İlerleyen zaman içerisinde arpa içerisinde bulunan yüksek protein, besinsel lifler ( $\beta$-glukan ve arabinoksilan gibi) nişasta ve selüloz miktarı gıda sektörünün dikkatini çekmiştir (Köten ve ark., 2013). 2013 yılında Türkiye'de yapılan bir çalışmada yaklaşık \%30 civarında kavuzsuz arpa unu içeren ekmek üretimi gerçekleştirilmiştir (Sayim ve ark., 2018).

2019 yılında dünya genelinde 141.2 milyon ton arpa üretimi gerçekleşmiştir (Anonim, 2020a). Türkiye'de ise 2.86 milyon hektar alanda 7.6 milyon ton arpa üretimi yapılmış ve ortalama verim 2.93 ton $\mathrm{ha}^{-1}$ olarak kaydedilmiştir (Anonim, 2020b). Bu üretim miktarının sadece 400 bin tonu maltlık, 6.6 milyon tonu ise yemlik arpa oluşturmuştur (Anonim, 2020a). Türkiye'de maltlık yönde ıslah edilmiş arpa çeşitlerinin az olması nedeniyle, malt fabrikaları mevcut çeşitlerden üretim ihtiyaçlarını (kalite analizi yaparak) karşılamaktadırlar. Malt sanayinin hızla gelişmesi, maltlık arpa ile ilgili çalışmalara hız kazandırmıştır (Candan, 2009). Yüksek verim potansiyeli olan ve malt sanayinin aradığı kalite kriterlerini taşıyan yeni arpa çeşitlerinin ıslahı, çiftçilere arpa tarımında daha yüksek gelir elde etme imkanı

*Sorumlu Yazar: soner.yuksel@tarimorman.gov.tr Bu çalışma TÜBITAK tarafından desteklenmiştir (Proje No: 105G083).

Geliş Tarihi: 30 Nisan 2021

Kabul Tarihi: 09 Aralık 2021 
verecektir (Sönmez ve ark, 2020). Eskişehir ilinde yetiştiriciliği yapılan kültür bitkileri içerisinde arpa ekonomik öneme sahiptir. Türkiye sıralamasında buğdayda 14. sırada, arpada 6. sırada yer almaktadır (Anonim 2020). Tane verimi ülke genelinde $293 \mathrm{~kg} / \mathrm{da}$ iken, Eskişehir'de ülke ortalamasının altında $(231 \mathrm{~kg} / \mathrm{da})$ gerçekleşmektedir. Bu sebeple, araştırma çalışmalarında bölge şartlarına uygun ve verim potansiyeli yüksek yeni arpa çeşitlerinin geliştirilmesi hedeflenmektedir. Hayvan beslenmesinde arpa samanı büyük önem arz etmektedir. Tahıllar arasında arpanın tuza toleransının yüksek olması (Munns ve ark., 2006) bu tip topraklarda üreticilerin arpa bitkisini tercih etmelerine sebep olmaktadır. Buğday bitkisine göre daha erkencilik özelliği gösteren arpanın sulu tarım yapılan sahalarda, birinci ürün olarak yetiştiriciliği artmaktadır (Öztürk ve ark., 2007).

Yıllık yağış toplamı ve aylara göre dağılımı oldukça düzensiz olan Orta Anadolu ve Geçit Bölgelerinde az miktarda yağış alınan yıllarda verim yönü ile stabil olan, yeterli yağış gerçekleşen dönemlerde ya da sulama imkânı olan alanlarda yatmaya dayanıklı ve verim potansiyeli yüksek olan çeşitlere gereksinim artmaktadır. Bu amaçla Orta Anadolu ve Batı Geçit Bölgesi iklim ve toprak şartlarına uygun, kışlık, yatmaya dayanıklı, orta erkenci, maltlık kalitesi yüksek ve verimli yeni çeşitlerin geliştirilerek arpa üretim miktarının artırılması ıslah programlarının başlıca amacını oluşturmaktadır.

\section{MATERYAL VE YÖNTEM}

Eskişehir Geçit Kuşağı Tarımsal Araştırma Enstitüsü'nde yürütülen arpa ıslah programında, 236 hat ve çeşitten oluşan arpa melez bahçesi iki ayrı zamanlı olarak ekilerek ıslah amacına uygun (yüksek verimli, kaliteli, hastalıklara, kurağa ve soğuğa dayanıklı) genotipleri elde etmek için çeşit veya hatlar aralarında melezlenmektedir. Bu çerçevede 1998 yılında yapılan melezlemede, ana olarak CWB117-5-95/ST5819 hattı ve baba olarak Kalaycı-97 çeşidi kullanılarak yeni bir çeşit geliştirilmesi amaçlanmıştır. Bu ebeveynlerin orijin ve özellikleri Çizelge 1 'de belirtilmiştir.

Islah programında modifiye edilmiş (değiştirilmiş) bulk metodu (Şehirali ve Özgen., 2007) uygulanmaktadır. Açılan generasyonların sonunda tek başak sıraları uygulanmakta olup buradan seçilen ıslah materyalinin önce gözlem bahçesinde sonraki yıllarda da verim denemelerinde seleksiyonları yapılmaktadır. Verim denemeleri Eskişehir merkez lokasyonunda kurulmakta ve üstün özellik gösteren materyal tescil ettirilmektedir. Araştırma, 2007 ve 2008 yıllarında, Eskişehir Geçit Kuşağı Tarımsal Araştırma Enstitüsü merkez arazisinde yürütülmüştür. Çalışmanın yürütüldüğü alanın denizden yüksekliği $780 \mathrm{~m}$ olup, $30^{\circ} 31^{\prime \prime}$ kuzey enlemleri $39^{\circ} 46^{\prime \prime}$ doğu boylamında yer almaktadır.
Çizelge 1. Melezlemede kullanılan ebeveynlerin orijin ve özellikleri Ingiltere orijinli, orta erkenci, kışa CWB117-5- dayanıklı, yatmaya hassas, $85 \mathrm{~cm}$. 9-5 ortalama boy uzunluğuna sahip, iki sıralı hat.

Enstitü stok materyalinde bulunan, arpa ST5819 hastalıklarına ve kışa dayanıklı, rastığa hassas, erkenci, altı sıralı hat.

Eskişehir Geçit Kuşağı Tarımsal Araştırma Enstitüsü Müdürlüğü tarafından melezleme yöntemi ile ıslah edilen, Erginel90//364TH/Tokak157/37

ebeveynlerinden oluşan ve 1997 yılında tescil ettirilen, uzun boylu, beyaz taneli, kışa dayanıklı, kardeşlenme kapasitesi ve

Kalaycı-97 malt kalitesi iyi, bölge şartlarında ortalama $300 \mathrm{~kg} / \mathrm{da}$ verime sahip, tarla şartlarında paslara yaprak leke ve çizgi hastalıklarına dayanıklı, bor toksisitesine, çinko eksikliğine ve Toprak Kaynaklı Mozaik Virüsü'ne orta dayanıklı, halen enstitü üretim programında sertifikalı tohumluk üretimi devam etmektedir.

Eskişehir ili her ne kadar batı geçit bölgesinde yer alsa da il genelinde karasal iklim hakimdir. Uzun yıllar yağış ortalamasına göre yıllık yağış miktarı $326.8 \mathrm{~mm}$ 'dir. Denemenin yürütüldüğü 2007 ve 2008 yetiştirme dönemlerine ve uzun yıllara ait aylık sıcaklık ve yağış değerleri Çizelge 2'de verilmiştir (Anonim, 2008). İklim verileri incelendiğinde iki yıl arasında yaklaşık 45 mm'lik bir yağış farkı gerçekleştiği görülmektedir. Illk yıl mayıs ayındaki yetersiz yağışın başaklanma döneminde olması her iki yıl arasında iklimsel açıdan farklılıkların oluşmasına neden olmuştur. Denemenin ilk yılında (2006-2007) alınan yağış miktarı (248.2 mm) uzun yılar ortalamasının (326.8 mm) yaklaşık $80 \mathrm{~mm}$ gerisinde, denemenin ikinci yılında (20072008) alınan yağış (293.3 mm) miktarı da uzun yıllar ortalamasının $33.5 \mathrm{~mm}$ gerisinde kalmıştır. Bu durum Eskişehir ilinde aylar ve yıllar itibarı ile gerçekleşen yağış miktarında dalgalanmalar olduğu ve uzun yıllar ile kıyaslandığında ciddi miktarda azalma meydana geldiğini göstermektedir.

Ekim öncesinde deneme alanının 3 farklı derinliklerden alınan toprak örneklerinin analizleri, Geçit Kuşağı Tarımsal Araştırma Enstitüsü, Toprak-Su Araştırmaları Laboratuvarlarında yapılmış ve bu analizlere ait sonuçlar Çizelge 3'de verilmiştir. Denemenin birinci yıl kurulduğu alandan alınan numunelerde yapılan analizlere göre toprak bünyesi killi, kireç ve organik madde içeriği bakımından orta, yarayışlı fosfor bakımından zayıf ve yarayışlı potasyum bakımından ise zengin özelliğe sahiptir. 
Çizelge 2. Denemenin yürütüldüğü yıllar ve uzun yıllara ait meteorolojik veriler (Anonim, 2008)

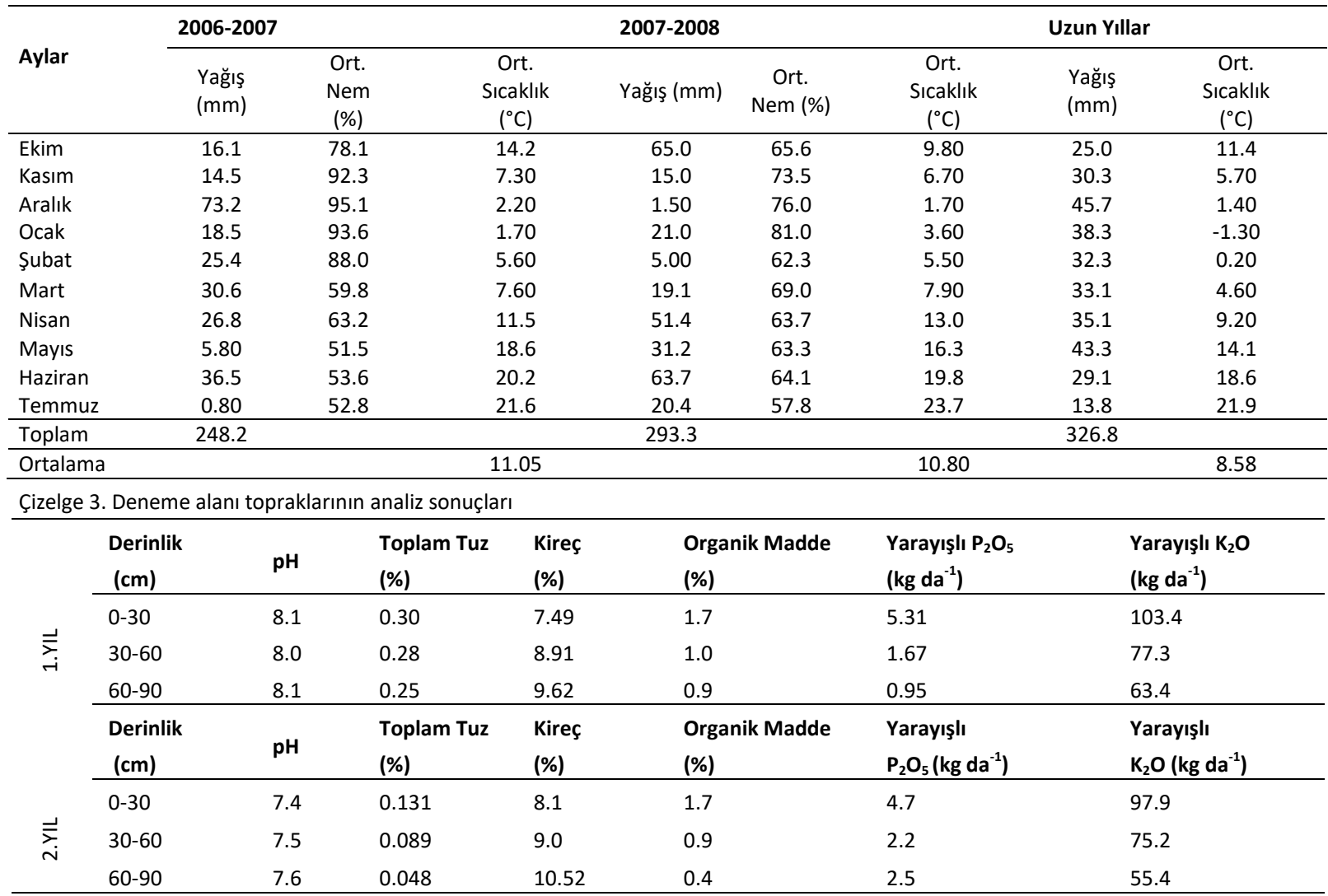

Bu çalışmada arpa ıslah projesi kapsamında bulunan 22 adet ileri kademe materyal ile 14 adet tescilli arpa çeşidi kullanılmıştır. Denemelerde kullanılan arpa hat ve çeşitlerinin isimleri Çizelge 4'de verilmiştir.

Çizelge 4. Denemede kullanılan hatların ve standart çeşitlerin isimleri

\begin{tabular}{llll}
\hline Genotip No & Hat/Çeşit İsmi & Genotip No & Hat/Çeşit İsmi \\
\hline 1 & MABVD-16 & 19 & KABVD14 \\
2 & MABVD-17 & 20 & KAVD-14 \\
3 & ADAY-2 & 21 & KAVD-17 \\
4 & ALTINOVA-2 & 22 & KABVD-23 \\
5 & OBVD-KA 12 & 23 & ABVD3-6 \\
6 & AYDANHANIM & 24 & ÇATALHÜYÜK \\
7 & OBVDA-KA16 & 25 & ABVD-10 \\
8 & AÖVD-2 (17) & 26 & AÖVD-3 \\
9 & BVD-2 & 27 & AÖVD-10 \\
10 & BVD-11 & 28 & BOLAYIR \\
11 & SABRiBEY & 29 & BURGAZ \\
12 & ZEYNELAĞA & 30 & ANADOLU-98 \\
13 & BVD-17 & 31 & EFES-2 \\
14 & BVD-21 & 32 & EFES-4 \\
15 & KAVD-3 & 33 & EFES-10 \\
16 & KAVD-5 & 34 & EFES-15 \\
17 & KAVD-6 & 35 & EFES-26 \\
18 & ÇUMRA & 36 & SLADORAN \\
\hline
\end{tabular}

Çalışma Tesadüf Blokları Deneme Deseninde 4 tekrarlamalı olarak yürütülmüş, her iki yılda tarla denemeleri nadas sonrası planlanarak ekimleri gerçekleştirilmiştir. Dekara $6 \mathrm{~kg}$ saf $\mathrm{N}$ (3 kg ekimle ve $3 \mathrm{~kg}$ sapa kalkma döneminde) ve ekimde $7.6 \mathrm{~kg}$ saf $\mathrm{P}_{2} \mathrm{O}_{5}$ (Çekiç ve ark., 2008) verilmiştir. Denemede 450 tohum $/ \mathrm{m}^{2}$ tohum sıklığı kullanılmıştır. Tohum ekimi, deneme mibzeri ile sıra arası $20 \mathrm{~cm}$ (6 sıra) ve $5 \mathrm{~m}$ uzunluğundaki parsellere yapılmıştır. Denemeler, 20062007 yetiştirme sezonunda 06 Ekim 2006 tarihinde ve 20072008 yetiştirme sezonunda 18 Ekim 2007 tarihinde kurulmuştur.

$\mathrm{Bu}$ araştırmanın ıslah çalışmalarında yapılan tüm fiziksel, protein ile malt ve mayşe analizleri ve değerlendirilmesi; Anonymous, 1960; Anonymous, 1986; Çelik ve Köksel., 1995; Ewertson, 1977; McCleary ve Codd., 1991; Sparrow, 1970; Türker, 1977; Uluöz, 1965; Williams ve ark., 1986; Yazıcıoğlu ve ark., 1976 ve Atlı ve ark., 1992'ye göre yapılırken tarla çalışmalarında alınan gözlemler ve değerlendirmeler ise Çölkesen ve ark., 1999; Akkaya ve Aktan., 1990 ve Tosun, 1993'e göre yapılmıştır.

\section{BULGULAR VE TARTIŞMA}

Sabribey çeşidi, 2007 ve 2008 yıllarında Eskişehir lokasyonunda yürütülen verim denemeleri sonuçlarına göre ilk yıl 675 kg/da verim ile ilk sırada yer alırken, deneme 
ortalamasından \%37 daha fazla verime ulaşmıştır. İkinci yıl $638 \mathrm{~kg} /$ da verim ile deneme ortalamasından \%14 daha fazla verim değeri göstermiş ve verim sıralamasında dördüncü sırada yer almıştır. Her iki yılın deneme ortalaması 529 $\mathrm{kg} /$ da olarak gerçekleşirken Sabribey çeşidi $656 \mathrm{~kg} /$ da verim ile ilk sırada yer almıştır (Çizelge 5). Denemede en yüksek hektolitre ağırlığı (HA), 25 numaralı hattan $(69.1 \mathrm{~kg} / \mathrm{hl})$ elde edilirken, Sabribey çeşidi $64.3 \mathrm{~kg} / \mathrm{hl}$ değeri ile deneme ortalaması olan $65.7 \mathrm{~kg} / \mathrm{hl}$ 'ye yakın bir değer göstermiştir (Çizelge 6). Bin tane ağırlığı (BTA) bakımından $31.9 \mathrm{~g}$ değerine sahip Sabribey çeşidi, deneme ortalamasından (35.8 g) daha düşük BTA'ya sahip olmuştur. Nişasta oranında (NO) ise sadece \%1.90'lık bir varyasyon meydana gelmiş ve genotiplerin ortalaması \%60.5 olarak gerçekleşmiştir. Sabribey çeşidi \%60.9 ile ortalama NO yakalamıştır.

Denemenin yürütüldüğü ilk yıl (2006-2007), uzun yıllar yağış ortalamasının (326.8 mm) oldukça altında gerçekleşen (248.2 mm) yağış nedeniyle (Çizelge 1) yüksek malt kalitesi için arzulanan protein oranının (PO <\%12) üzerinde (\%14.0) bir PO saptanmıştır (Çizelge 6). Sabribey çeşidinin PO \%13.9 ile deneme ortalamasına benzer sonuç gösterirken 5 numaralı hattın PO \%18.3 ile en yüksek PO’na ulaşmıştır.

Çizelge 5. Incelenen arpa genotiplerinin 2007 ve 2008 yıllarına ait verim değerleri (kg/da)

\begin{tabular}{|c|c|c|c|c|}
\hline Çeşit/Hat No & Çeşit/Hat & 2007 Yilı & 2008 Yilı & Ortalama \\
\hline 1 & MABVD-16 & $495^{\mathrm{d}-1}$ & $578^{\mathrm{a}-\mathrm{g}}$ & 536 \\
\hline 2 & MABVD-17 & $546^{a-f}$ & $541^{\text {efg }}$ & 538 \\
\hline 3 & ADAY-2 & $493^{d-1}$ & $569^{a-g}$ & 531 \\
\hline 4 & ALTINOVA-2 & $583^{a-d}$ & $574^{a-g}$ & 578 \\
\hline 5 & OBVD-KA 12 & $496^{d-1}$ & $591^{a-f}$ & 543 \\
\hline 6 & AYDANHANIM & $497^{d-1}$ & $523^{\mathrm{fgh}}$ & 510 \\
\hline 7 & OBVDA-KA16 & $381^{1-j}$ & $547^{d-g}$ & 464 \\
\hline 8 & AÖVD-2 (17) & $429^{f-j}$ & $570^{a-g}$ & 499 \\
\hline 9 & BVD-2 & $658^{\mathrm{ab}}$ & $637^{a-d}$ & 647 \\
\hline 10 & BVD-11 & $640^{a b c}$ & $621^{a-e}$ & 630 \\
\hline 11 & SABRIBEY & $675^{a}$ & $638^{a-d}$ & 656 \\
\hline 12 & ZEYNELAĞA & $515^{c-h}$ & $511^{\mathrm{fgh}}$ & 513 \\
\hline 13 & BVD-17 & $483^{d-1}$ & $639^{a-b-c}$ & 561 \\
\hline 14 & BVD-21 & $673^{a}$ & $641^{a-b}$ & 657 \\
\hline 15 & KAVD-3 & $450^{\mathrm{e}-1}$ & $622^{a-e}$ & 536 \\
\hline 16 & KAVD-5 & $493^{d-1}$ & $593^{a-f}$ & 543 \\
\hline 17 & KAVD-6 & $470^{\mathrm{d}-1}$ & $654^{a}$ & 562 \\
\hline 18 & ÇUMRA & $457^{d-1}$ & $539^{\mathrm{efg}}$ & 498 \\
\hline 19 & KABVD14 & $453^{d-1}$ & $593^{a-g}$ & 523 \\
\hline 20 & KAVD-14 & $525^{c-g}$ & $583^{a-g}$ & 554 \\
\hline 21 & KAVD-17 & $489^{d-1}$ & $549^{c-g}$ & 519 \\
\hline 22 & KABVD-23 & $490^{d-1}$ & $596^{a-f}$ & 543 \\
\hline 23 & ABVD3-6 & $304^{j}$ & $322^{\prime}$ & 313 \\
\hline 24 & ÇATALHÜYÜK & $388^{h i j}$ & $582^{a-g}$ & 485 \\
\hline 25 & ABVD-10 & $521^{c-g}$ & $580^{a-g}$ & 550 \\
\hline 26 & AÖVD-3 & $377^{1-j}$ & $444^{h-1}$ & 410 \\
\hline 27 & AÖVD-10 & $479^{d-1}$ & $440^{\mathrm{h}-1}$ & 459 \\
\hline 28 & BOLAYIR & $515^{c-h}$ & $567^{a-g}$ & 541 \\
\hline 29 & BURGAZ & $381^{1-j}$ & $499^{g-h}$ & 440 \\
\hline 30 & ANADOLU-98 & $460^{d-1}$ & $550^{\mathrm{b}-\mathrm{g}}$ & 505 \\
\hline 31 & EFES-2 & $413^{g-j}$ & $555^{\mathrm{b}-\mathrm{g}}$ & 484 \\
\hline 32 & EFES-4 & $575^{\text {ae }}$ & $594^{a-f}$ & 584 \\
\hline 33 & EFES-10 & $490^{\mathrm{d}-1}$ & $562^{a-g}$ & 526 \\
\hline 34 & EFES-15 & $554^{\mathrm{a}-\mathrm{f}}$ & $587^{\mathrm{a}-\mathrm{g}}$ & 570 \\
\hline 35 & EFES-26 & $533^{b-g}$ & $571^{\mathrm{a}-\mathrm{g}}$ & 552 \\
\hline 36 & SLADORAN & $425^{f-j}$ & $543^{\text {efg }}$ & 484 \\
\hline \multicolumn{2}{|l|}{ Ortalama } & 494 & 564 & 529 \\
\hline \multicolumn{2}{|c|}{ Varyasyon Katsayısı (\%) } & 16.2 & 9.00 & \\
\hline \multicolumn{2}{|c|}{ Asgari Önemli Fark $_{(0,05)}$} & 129 & 110 & \\
\hline
\end{tabular}




\begin{tabular}{|c|c|c|c|c|c|c|c|c|}
\hline $\begin{array}{l}\text { Çeşit/ } \\
\text { Hat } \\
\text { No }\end{array}$ & Çeşit/Hat & $\begin{array}{l}\text { Hektolitre } \\
\text { Ăg. }(\mathrm{kg} / \mathrm{hl})\end{array}$ & $\begin{array}{l}1000 \text { Tane } \\
\text { Ăg. (g) }\end{array}$ & $\begin{array}{l}\text { Nişasta } \\
\text { (\%) }\end{array}$ & $\begin{array}{l}\text { Tanede } \\
\text { Protein (\%) }\end{array}$ & $\begin{array}{l}2,5 \mathrm{~mm} \text { Elek } \\
\text { Üstü (\%) }\end{array}$ & $\begin{array}{l}\text { Elek Altı } \\
\text { (\%) }\end{array}$ & $\begin{array}{l}\text { İrilik } \\
\text { Sinıfı }\end{array}$ \\
\hline 1 & MABVD-16 & 68.0 & 36.6 & 59.2 & 16.1 & 63.7 & 3.00 & 6 \\
\hline 2 & MABVD-17 & 66.9 & 33.2 & 59.7 & 15.3 & 44.8 & 8.30 & 10 \\
\hline 3 & ADAY-2 & 63.7 & 36.0 & 60.2 & 14.9 & 48.9 & 7.90 & 10 \\
\hline 4 & ALTINOVA-2 & 65.5 & 36.0 & 59.4 & 15.2 & 47.2 & 7.30 & 9 \\
\hline 5 & OBVD-KA-12 & 60.0 & 34.0 & 56.9 & 18.3 & 26.0 & 16.1 & 15 \\
\hline 6 & AYDANHANIM & 65.7 & 36.8 & 60.3 & 14.5 & 56.2 & 2.20 & 6 \\
\hline 7 & OBVD-KA-16 & 68.1 & 37.0 & 60.4 & 15.0 & 53.4 & 3.40 & 7 \\
\hline 8 & AÖVD(2)-17 & 64.7 & 33.5 & 59.9 & 14.4 & 32.0 & 13.5 & 13 \\
\hline 9 & BVD-2 & 58.5 & 31.0 & 58.9 & 15.5 & 26.2 & 16.4 & 15 \\
\hline 10 & BVD-11 & 66.8 & 33.2 & 60.6 & 14.2 & 41.0 & 8.00 & 10 \\
\hline 11 & SABRIBEY & 64.3 & 31.9 & 60.9 & 13.9 & 45.2 & 5.00 & 8 \\
\hline 12 & ZEYNELAĞA & 67.7 & 39.5 & 60.6 & 14.4 & 81.7 & 1.10 & 3 \\
\hline 13 & BVD-17 & 66.5 & 35.8 & 59.6 & 15.4 & 41.8 & 7.80 & 10 \\
\hline 14 & BVD-21 & 65.4 & 36.5 & 60.8 & 13.3 & 53.9 & 3.42 & 7 \\
\hline 15 & KAVD-3 & 63.1 & 34.9 & 60.1 & 14.0 & 30.6 & 17.2 & 14 \\
\hline 16 & KAVD-5 & 65.9 & 34.7 & 59.9 & 14.5 & 44.5 & 8.51 & 10 \\
\hline 17 & KAVD-6 & 65.0 & 28.7 & 60.0 & 13.5 & 35.8 & 15.2 & 14 \\
\hline 18 & ÇUMRA & 65.3 & 37.1 & 61.1 & 12.7 & 65.9 & 3.40 & 6 \\
\hline 19 & KABVD-14 & 65.1 & 32.8 & 58.9 & 16.4 & 27.5 & 14.6 & 14 \\
\hline 20 & KAVD-14 & 64.1 & 34.5 & 60.7 & 12.9 & 34.5 & 15.5 & 14 \\
\hline 21 & KAVD-17 & 64.0 & 33.7 & 59.8 & 14.8 & 47.4 & 9.00 & 10 \\
\hline 22 & KABVD-23 & 67.8 & 33.3 & 61.7 & 13.4 & 42.5 & 8.61 & 10 \\
\hline 23 & ABVD3-6 & 66.9 & 30.6 & 62.0 & 11.9 & 30.4 & 12.6 & 12 \\
\hline 24 & ÇATALHÖYÜK & 65.5 & 37.1 & 62.2 & 10.2 & 48.3 & 5.81 & 9 \\
\hline 25 & $A B V D-10$ & 69.1 & 41.0 & 61.7 & 13.2 & 60.9 & 3.80 & 6 \\
\hline 26 & AÖVD-3 & 67.3 & 43.2 & 59.8 & 14.9 & 92.9 & 0.21 & 2 \\
\hline 27 & AÖVD-10 & 67.4 & 39.1 & 59.8 & 14.7 & 78.0 & 1.20 & 4 \\
\hline 28 & BOLAYIR & 66.9 & 40.5 & 61.2 & 12.9 & 72.1 & 2.30 & 4 \\
\hline 29 & BURGAZ & 68.9 & 40.1 & 60.3 & 13.8 & 83.6 & 0.41 & 3 \\
\hline 30 & ANADOLU-98 & 66.7 & 37.2 & 62.5 & 11.1 & 48.2 & 5.40 & 9 \\
\hline 31 & EFES-2 & 66.3 & 33.9 & 60.5 & 15.0 & 47.9 & 7.50 & 10 \\
\hline 32 & EFES-4 & 63.8 & 35.7 & 61.0 & 13.6 & 41.0 & 11.3 & 11 \\
\hline 33 & EFES-10 & 66.1 & 38.2 & 61.1 & 13.5 & 56.6 & 5.80 & 8 \\
\hline 34 & EFES-15 & 64.4 & 38.8 & 61.0 & 13.6 & 64.6 & 6.81 & 7 \\
\hline 35 & EFES-26 & 65.9 & 35.9 & 63.0 & 10.8 & 58.8 & 4.20 & 7 \\
\hline 36 & SLADORAN & 67.7 & 37.6 & 61.3 & 12.5 & 82.5 & 0.70 & 3 \\
\hline \multicolumn{2}{|c|}{ Ortalama } & 65.7 & 35.8 & 60.5 & 14.0 & 51.6 & 7.32 & 8.80 \\
\hline \multicolumn{2}{|c|}{ Varyasyon katsayısı (\%) } & 3.30 & 8.70 & 1.90 & 11.3 & 34.0 & 69.3 & 41.7 \\
\hline
\end{tabular}


Çizelge 7. İncelenen arpa genotiplerinin 2007 yılına ait teknolojik analiz değerleri (Devamı)

\begin{tabular}{|c|c|c|c|c|c|c|c|c|}
\hline $\begin{array}{l}\text { Çeşit/ } \\
\text { Hat No }\end{array}$ & Çeşit/Hat & $\begin{array}{l}\text { Çimlenme } \\
\text { Kabiliyeti } \\
(\%)\end{array}$ & $\begin{array}{l}\text { Kavuz } \\
\text { Oranı } \\
(\%) \\
\end{array}$ & $\begin{array}{l}\text { Friabilite } \\
\text { Değeri } \\
(\%)\end{array}$ & $\begin{array}{l}\text { Ince } \\
\text { Ekstrakt } \\
(\%) \\
\end{array}$ & $\begin{array}{l}\text { Ekstrakt } \\
\text { Farkı } \\
(\%) \\
\end{array}$ & $\begin{array}{l}\text { Hartong } \\
\text { Sayısı } \\
(\%) \\
\end{array}$ & $\begin{array}{l}\text { Kolbach } \\
\text { Sayısı } \\
(\%) \\
\end{array}$ \\
\hline 1 & MABVD-16 & 98 & 8.4 & 51.9 & 72.2 & 6.5 & $* *$ & 48.7 \\
\hline 2 & MABVD-17 & 92 & 8.8 & 40.4 & 73.9 & 6.5 & 45.4 & 57.4 \\
\hline 3 & ADAY-2 & 82 & 8.3 & 39.2 & 72.2 & 0.5 & 41.1 & 44.3 \\
\hline 4 & ALTINOVA-2 & 93 & 10.4 & 25.1 & 71.4 & 0.7 & $* *$ & $* *$ \\
\hline 5 & OBVD-KA-12 & 100 & 8.6 & 24.8 & 70.2 & 2.4 & $* *$ & $* *$ \\
\hline 6 & AYDANHANIM & 98 & 9.2 & 47.7 & 73.8 & 0.5 & $* *$ & 58.1 \\
\hline 7 & OBVD-KA-16 & 96 & 8.2 & 47.9 & 76.4 & 3.1 & 45.6 & 60.4 \\
\hline 8 & AÖVD(2)-17 & 97 & 9.3 & 38.5 & 74.4 & 2.6 & $* *$ & 57.1 \\
\hline 9 & BVD-2 & 94 & 9.3 & 53.2 & 77.0 & 0.5 & 39.2 & 75.8 \\
\hline 10 & BVD-11 & 100 & 9.3 & 53.8 & 76.1 & 0.3 & $* *$ & 63.6 \\
\hline 11 & SABRIBEY & 99 & 10.2 & 51.9 & 75.2 & 1.2 & 35.7 & 57.6 \\
\hline 12 & ZEYNELAĞA & 98 & 10.2 & 42.5 & 72.2 & 0.7 & 42.5 & 40.7 \\
\hline 13 & BVD-17 & 100 & 8.1 & 43.2 & 72.2 & 1.0 & $* *$ & 59.2 \\
\hline 14 & BVD-21 & 98 & 10.1 & 63.6 & 75.3 & 1.3 & 42.6 & 48.7 \\
\hline 15 & KAVD-3 & 100 & 8.5 & 45.0 & 75.3 & 3.3 & 40.3 & 50.2 \\
\hline 16 & KAVD-5 & 97 & 8.9 & 68.9 & 77.2 & 2.3 & $* *$ & 77.1 \\
\hline 17 & KAVD-6 & 93 & 9.0 & 25.4 & 74.6 & 2.7 & $* *$ & $* *$ \\
\hline 18 & ÇUMRA & 94 & 10.2 & 56.0 & 80.2 & 1.3 & 41.8 & 59.5 \\
\hline 19 & KABVD-14 & 92 & 9.7 & 42.4 & 74.2 & 1.9 & 42.6 & 49.1 \\
\hline 20 & KAVD-14 & 98 & 9.3 & 57.4 & 75.5 & 0.5 & 43.1 & 73.0 \\
\hline 21 & KAVD-17 & 99 & 9.4 & 45.1 & 74.4 & 1.4 & 44.0 & 56.9 \\
\hline 22 & KABVD-23 & 100 & 12.5 & 46.7 & 78.2 & 0.3 & 38.3 & 78.2 \\
\hline 23 & ABVD3-6 & 92 & 9.8 & 49.6 & 76.0 & 3.3 & 40.1 & 68.5 \\
\hline 24 & ÇATALHÖYÜK & 97 & 10.0 & 38.0 & 75.8 & 2.3 & $* *$ & $* *$ \\
\hline 25 & ABVD-10 & 98 & 8.2 & 45.4 & 72.1 & 0.3 & 44.4 & 44.3 \\
\hline 26 & AÖVD-3 & 98 & 8.5 & 40.8 & 75.6 & 3.5 & $* *$ & 57.0 \\
\hline 27 & AÖVD-10 & 98 & 10.3 & 42.8 & 75.9 & 1.4 & 49.5 & 51.2 \\
\hline 28 & BOLAYIR & 100 & 8.7 & 45.2 & 75.8 & 2.5 & 51.2 & 48.6 \\
\hline 29 & BURGAZ & 90 & 8.0 & 69.5 & 79.4 & 0.8 & 52.0 & 73.0 \\
\hline 30 & ANADOLU-98 & 96 & 9.5 & 63.3 & 79.5 & 2.2 & $* *$ & 97.8 \\
\hline 31 & EFES-2 & 84 & 8.2 & 41.8 & 73.7 & 1.2 & $* *$ & 58.6 \\
\hline 32 & EFES-4 & 93 & 9.7 & 54.9 & 75.4 & 0.7 & 38.8 & 64.6 \\
\hline 33 & EFES-10 & 97 & 9.3 & 53.1 & 73.0 & 3.5 & 42.2 & 81.3 \\
\hline 34 & EFES-15 & 99 & 8.8 & 37.9 & 74.2 & 3.2 & $* *$ & $* *$ \\
\hline 35 & EFES-26 & 100 & 8.8 & 66.3 & 76.5 & 1.0 & 41.2 & 53.7 \\
\hline 36 & SLADORAN & 87 & 10.5 & 50.6 & 76.4 & 0.2 & 41.1 & 55.7 \\
\hline \multicolumn{2}{|l|}{ Ortalama } & 95.8 & 9.3 & 47.5 & 75.0 & 1.9 & 42.8 & 60.9 \\
\hline \multicolumn{2}{|c|}{ Varyasyon katsayısı (\%) } & 4.7 & 9.9 & 23.2 & 3.1 & 82.7 & 9.6 & 21.3 \\
\hline
\end{tabular}


YÜKSEL S, AKAR T, SAYIM I, ERGÜN N, AYDOĞAN S, ŞENAL T, GÜLER S, BELEN S, SÖNMEZ AC

En yüksek elek üstü (EÜ) değeri 26 numaralı hatta (\%92.9) ölçülmüştür. Lokasyonun EÜ değeri ortalaması \%51.6 kaydedilmesine rağmen, bu değer malt kalitesi açısından düşük bir değerdir. Bunun yanında elek altı (EA) \%69.3 irilik sınıfında \%41.7'lik bir varyasyon meydana gelmiştir. En iyi irilik sınıfı 2 değeri ile 26 nolu hatta meydana gelirken
Sabribey çeşidi 8 değeri ile deneme ortalamasından (8.80) daha iyi bir değer göstermiştir. Sabribey çeşidinde çimlenme oranı (ÇO) \%99 olarak gerçekleşirken denemedeki dane örneklerinde çO \%84 ile \%100 arasında değişmiştir (Çizelge 7).

Çizelge 8. İncelenen arpa genotiplerinin 2008 yılına ait teknolojik analiz değerleri

\begin{tabular}{|c|c|c|c|c|c|c|c|c|}
\hline $\begin{array}{l}\text { Çeşit, } \\
\text { Hat } \\
\text { No }\end{array}$ & Çeşit/Hat & Hlt Ăg (kg/hl) & $\begin{array}{l}1000 \text { Tane Ağ. } \\
\text { (g) }\end{array}$ & Nişasta (\%) & $\begin{array}{l}\text { Tanede } \\
\text { Protein (\%) }\end{array}$ & $\begin{array}{l}2,5 \text { mm Elek } \\
\text { Üstü (\%) }\end{array}$ & $\begin{array}{l}\text { Elek Altı } \\
\text { (\%) }\end{array}$ & İrilik Sınıfı \\
\hline 1 & MABVD-16 & 75.1 & 36.9 & 62.9 & 12.2 & 89.5 & 1.2 & 3 \\
\hline 2 & MABVD-17 & 74.8 & 43.8 & 63.2 & 11.7 & 83.1 & 3.0 & 4 \\
\hline 3 & ADAY-2 & 73.8 & 39.0 & 63.8 & 11.5 & 75.5 & 2.1 & 4 \\
\hline 4 & ALTINOVA-2 & 75.2 & 41.1 & 63.6 & 10.7 & 80.6 & 3.0 & 5 \\
\hline 5 & OBVD-KA-12 & 75.2 & 39.0 & 64.3 & 9.40 & 84.5 & 2.3 & 3 \\
\hline 6 & AYDANHANIM & 76.0 & 40.3 & 65.1 & 8.80 & 93.3 & 1.5 & 2 \\
\hline 7 & OBVD-KA-16 & 73.5 & 43.7 & 62.8 & 11.5 & 75.9 & 3.9 & 5 \\
\hline 8 & AÖVD(2)-17 & 72.6 & 36.7 & 63.0 & 11.4 & 65.8 & 8.1 & 8 \\
\hline 9 & BVD-2 & 70.3 & 38.7 & 63.6 & 10.7 & 32.0 & 17.9 & 15 \\
\hline 10 & BVD-11 & 75.1 & 40.6 & 65.3 & 10.1 & 76.6 & 2.7 & 5 \\
\hline 11 & SABRIBEY & 74.1 & 30.8 & 64.9 & 9.40 & 88.4 & 2.4 & 3 \\
\hline 12 & ZEYNELAĞA & 73.3 & 40.1 & 63.3 & 9.60 & 91.5 & 1.2 & 2 \\
\hline 13 & BVD-17 & 73.6 & 42.2 & 62.5 & 11.9 & 78.0 & 3.3 & 5 \\
\hline 14 & BVD-21 & 70.1 & 35.5 & 62.6 & 12.2 & 48.8 & 6.3 & 9 \\
\hline 15 & KAVD-3 & 72.1 & 38.5 & 62.3 & 12.2 & 65.6 & 7.1 & 7 \\
\hline 16 & KAVD-5 & 74.5 & 40.3 & 63.0 & 11.3 & 62.9 & 6.5 & 7 \\
\hline 17 & KAVD-6 & 74.4 & 42.4 & 64.5 & 10.6 & 83.9 & 2.5 & 3 \\
\hline 18 & ÇUMRA & 74.4 & 40.3 & 65.1 & 9.50 & 90.6 & 2.1 & 2 \\
\hline 19 & KABVD-14 & 71.4 & 41.4 & 61.9 & 12.4 & 79.0 & 3.0 & 5 \\
\hline 20 & KAVD-14 & 73.1 & 37.3 & 62.9 & 11.9 & 68.4 & 5.5 & 7 \\
\hline 21 & KAVD-17 & 73.7 & 37.8 & 62.8 & 11.9 & 68.6 & 6.2 & 7 \\
\hline 22 & KABVD-23 & 75.4 & 42.5 & 64.0 & 10.8 & 87.7 & 1.6 & 3 \\
\hline 23 & ABVD3-6 & 72.4 & 27.1 & 63.0 & 11.8 & 25.2 & 27.8 & 16 \\
\hline 24 & ÇATALHÖYÜK & 74.8 & 43.4 & 62.6 & 9.90 & 90.4 & 1.3 & 2 \\
\hline 25 & ABVD-10 & 73.2 & 42.5 & 62.2 & 12.7 & 90.4 & 1.1 & 2 \\
\hline 26 & AÖVD-3 & 74.6 & 47.0 & 61.6 & 13.3 & 97.4 & 0.6 & 2 \\
\hline 27 & AÖVD-10 & 73.2 & 41.8 & 59.7 & 14.5 & 91.9 & 1.1 & 2 \\
\hline 28 & BOLAYIR & 75.1 & 35.5 & 63.0 & 12.3 & 88.7 & 1.6 & 2 \\
\hline 29 & BURGAZ & 75.4 & 41.2 & 62.8 & 11.9 & 96.6 & 0.8 & 2 \\
\hline 30 & ANADOLU-98 & 75.8 & 44.2 & 65.4 & 9.00 & 92.9 & 0.9 & 2 \\
\hline 31 & EFES-2 & 72.8 & 35.9 & 62.5 & 12.1 & 67.6 & 7.6 & 7 \\
\hline 32 & EFES-4 & 72.3 & 38.6 & 63.2 & 11.6 & 74.4 & 4.7 & 5 \\
\hline 33 & EFES-10 & 75.0 & 39.2 & 64.7 & 10.4 & 84.7 & 2.9 & 4 \\
\hline 34 & EFES-15 & 74.4 & 41.3 & 65.6 & 9.90 & 93.1 & 1.4 & 2 \\
\hline 35 & EFES-26 & 74.6 & 41.2 & 65.9 & 9.40 & 90.4 & 1.6 & 2 \\
\hline 36 & SLADORAN & 73.1 & 38.6 & 63.9 & 10.6 & 94.6 & 0.8 & 2 \\
\hline \multicolumn{2}{|c|}{ Ortalama } & 73.8 & 39.6 & 63.4 & 11.1 & 79.1 & 4.1 & 4.6 \\
\hline \multicolumn{2}{|c|}{ Varyasyon katsayısı (\%) } & 2.00 & 9.40 & 2.00 & 11.7 & 21.2 & 127 & 73.4 \\
\hline
\end{tabular}


Çizelge 9. İncelenen arpa genotiplerinin 2008 yılına ait teknolojik analiz değerleri (Devamı)

\begin{tabular}{|c|c|c|c|c|c|c|c|c|}
\hline $\begin{array}{l}\text { Çeşit/ } \\
\text { Hat } \\
\text { No }\end{array}$ & Çeşit/Hat & $\begin{array}{l}\text { Çimlenme } \\
\text { Kabiliyeti } \\
(\%)\end{array}$ & $\begin{array}{l}\text { Kavuz Oranı } \\
\text { (\%) }\end{array}$ & $\begin{array}{l}\text { Friabilite } \\
\text { Değeri } \\
(\%)\end{array}$ & $\begin{array}{l}\text { İnce } \\
\text { Ekstrakt } \\
(\%)\end{array}$ & $\begin{array}{l}\text { Ekstrakt } \\
\text { Farkı } \\
(\%)\end{array}$ & $\begin{array}{l}\text { Hartong } \\
\text { Sayısı } \\
(\%)\end{array}$ & $\begin{array}{l}\text { Kolbach } \\
\text { Sayısı (\%) }\end{array}$ \\
\hline 1 & MABVD-16 & 99 & 8.00 & 55.7 & 79.0 & 1.42 & 39.3 & 47.0 \\
\hline 2 & MABVD-17 & 99 & 8.20 & 61.4 & 79.8 & 3.45 & 38.8 & 50.9 \\
\hline 3 & ADAY-2 & 98 & 8.60 & 56.9 & 77.8 & 1.42 & 38.2 & 57.0 \\
\hline 4 & ALTINOVA-2 & 97 & 9.30 & 65.8 & 79.2 & 1.94 & 39.7 & 65.3 \\
\hline 5 & OBVD-KA-12 & 97 & 8.00 & 64.2 & 81.6 & 2.76 & 30.8 & 76.1 \\
\hline 6 & AYDANHANIM & 99 & 8.50 & 82.3 & 83.1 & 3.47 & 39.6 & 99.2 \\
\hline 7 & OBVD-KA-16 & 99 & 8.50 & 54.4 & 81.8 & 2.80 & 35.0 & 66.8 \\
\hline 8 & AÖVD(2)-17 & 98 & 7.50 & 49.4 & 78.5 & 1.93 & 32.6 & 65.8 \\
\hline 9 & BVD-2 & 99 & 9.00 & 74.5 & 80.0 & 2.06 & 34.2 & 73.9 \\
\hline 10 & BVD-11 & 99 & 8.30 & 73.9 & 81.4 & 2.27 & 41.8 & 76.4 \\
\hline 11 & SABRIBEY & 98 & 9.50 & 85.4 & 78.9 & 0.91 & 37.0 & 102 \\
\hline 12 & ZEYNELAĞA & 99 & 9.30 & 87.1 & 80.0 & 1.03 & 40.6 & 87.6 \\
\hline 13 & BVD-17 & 100 & 9.90 & 67.7 & 78.1 & 1.02 & 33.0 & 66.5 \\
\hline 14 & BVD-21 & 100 & 7.80 & 69.6 & 77.9 & 2.73 & $* *$ & 51.9 \\
\hline 15 & KAVD-3 & 97 & 7.70 & 45.6 & 77.5 & 1.01 & 31.5 & 73.8 \\
\hline 16 & KAVD-5 & 100 & 7.50 & 67.1 & 81.2 & 3.49 & 39.7 & 72.2 \\
\hline 17 & KAVD-6 & 97 & 9.00 & 59.0 & 79.3 & 4.66 & 36.1 & 70.8 \\
\hline 18 & ÇUMRA & 99 & 8.50 & 70.1 & 79.8 & 1.23 & 33.6 & 61.5 \\
\hline 19 & KABVD-14 & 99 & 7.80 & 53.6 & 77.4 & 1.72 & 42.1 & 53.2 \\
\hline 20 & KAVD-14 & 100 & 7.90 & 57.1 & 77.4 & 2.93 & 37.1 & 56.3 \\
\hline 21 & KAVD-17 & 100 & 7.60 & 53.3 & 78.6 & 0.71 & $* *$ & 69.3 \\
\hline 22 & KABVD-23 & 99 & 8.40 & 59.6 & 80.0 & 1.33 & 37.0 & 77.7 \\
\hline 23 & ABVD3-6 & 99 & 8.10 & 61.8 & 78.7 & 3.24 & 34.2 & 49.2 \\
\hline 24 & ÇATALHÖYÜK & 98 & 7.80 & 58.6 & 81.0 & 1.03 & 29.2 & 78.0 \\
\hline 25 & ABVD-10 & 100 & 8.10 & 51.0 & 76.5 & 2.24 & 36.2 & 56.5 \\
\hline 26 & AÖVD-3 & 100 & 9.00 & 50.1 & 75.2 & 1.72 & 40.8 & 55.6 \\
\hline 27 & AÖVD-10 & 99 & 8.30 & 63.6 & 77.2 & 3.15 & 52.9 & 70.4 \\
\hline 28 & BOLAYIR & 99 & 8.50 & 91.3 & 81.5 & 1.03 & 46.7 & 64.1 \\
\hline 29 & BURGAZ & 98 & 8.80 & 82.9 & 80.6 & 1.03 & 48.2 & 89.2 \\
\hline 30 & ANADOLU-98 & 99 & 8.50 & 62.6 & 80.8 & 1.23 & 30.1 & 74.6 \\
\hline 31 & EFES-2 & 100 & 8.50 & 71.0 & 79.9 & 0.82 & 35.5 & 61.0 \\
\hline 32 & EFES-4 & 99 & 8.40 & 70.5 & 80.1 & 0.72 & 36.2 & 62.8 \\
\hline 33 & EFES-10 & 99 & 9.60 & 67.0 & 79.0 & 0.92 & 38.2 & 85.5 \\
\hline 34 & EFES-15 & 98 & 8.00 & 79.4 & 81.7 & 0.82 & 44.1 & 59.3 \\
\hline 35 & EFES-26 & 98 & 8.10 & 85.0 & 81.5 & 0.72 & $* *$ & 80.3 \\
\hline 36 & SLADORAN & 100 & 8.90 & 85.8 & 80.5 & 0.52 & 46.2 & 93.7 \\
\hline \multicolumn{2}{|c|}{ Ortalama } & 98.8 & 8.40 & 67.0 & 79.6 & 1.80 & 38.0 & 70.7 \\
\hline \multicolumn{2}{|c|}{ Varyasyon katsayısı (\%) } & 1.00 & 7.20 & 18.5 & 2.20 & 58.2 & 14.6 & 18.9 \\
\hline
\end{tabular}


YÜKSEL S, AKAR T, SAYIM i, ERGÜN N, AYDOĞAN S, ŞENAL T, GÜLER S, BELEN S, SÖNMEZ AC

En yüksek friabilite değeri \%69.5 ile Burgaz çeşidinden elde edilirken Sabribey çeşidi \%51.9 ile deneme ortalamasından (\%47.5) \%4.4 daha yüksek değer göstermiştir. En yüksek ekstrakt verimine Çumra çeşidinde (\%80.2) en düşük orana da 4 nolu hatta rastlanmış (\%71.4) Sabribey çeşidi \%75.2 ile deneme ortalamasını çok az bir değerle geçmiştir. Genotiplerinin çoğunun malt ekstrakt düzeyi dünyaca kabul gören \%76-82 bandına daha yakın olarak meydana gelmiştir.

2008 yılında yürütülen denemede en yüksek HA 76.0 kg/hl ile Aydanhanım çeşidinde belirlenirken ortalama $73.8 \mathrm{~kg} / \mathrm{hl}$ olarak gerçekleşmiş Sabribey çeşidi $74.1 \mathrm{~kg} / \mathrm{hl}$ değeri ile deneme ortalamasının üzerinde yer almıştır (Çizelge 8). BTA değerleri bakımından deneme ortalaması $39.6 \mathrm{~g}$ iken 26 nolu hat $47.0 \mathrm{~g}$ ile ilk sırada yer almış, çeşidimiz $30.8 \mathrm{~g}$ ile oldukça düşük bir değer göstermiştir. NO değerleri incelendiğinde en yüksek değer \%65.9 ile Efes-26 çeşidinden elde edilmiş, Sabribey çeşidi \%64.9 ile deneme ortalamasını geçmiştir. PO değerleri bakımından en yüksek 27 nolu hatta (\%14.5) en düşük ise Aydanhanım çeşidinde rastlanmıştır. 2008 yılında yürütülen denemede genel olarak yüksek malt kalitesi için arzulanan bir PO saptanmıştır. Yüksek malt kalitesine ulaşmada çevrenin etkisi ikinci yılda açıkça ortaya çıkmıştır. Çalışmada $2,5 \mathrm{~mm}$ EÜ ortalaması \%79.1, EA \%2.4 ve irilik sınıfı ortalaması 4.6 olarak gerçekleşirken Sabribey çeşidi sırasıyla \%88.4, \%2.4 ve 3 değerleri ile ortalamalardan daha yüksek sonuçlar vermiştir.

ÇO bakımından çevre ortalaması \%98.8 olarak gerçekleşmiş, genel olarak tüm çeşit ve hatlarda arzu edilen çO yaklaşılmıştır (Çizelge 9). KO bakımından varyasyon \%7.2 olup 8 ve 16 nolu hatlar en düşük KO'na sahip olmuşlardır. Sabribey çeşidi \%9.50 KO değeri ile deneme ortalamasının (\%8.40) üzerinde bir değer göstermiştir. Yapılan friabilite analizleri sonucu genotipler arasında \%18.5'lik bir varyasyona rastlanmıştır. Genotiplerin friabilite değerleri \%91.3 (Bolayır) ve 45.6 (Hat 15) arasında değişmiş, Sabribey çeşidinde \%85.4 değeri elde edilmiştir. En yüksek ince ekstrakt verimine Aydanhanım çeşidinde (\%83.17), en düşük orana da 20 nolu hatta rastlanmıştır (\%76.54). Ortalama ince ekstrakt verimi \%79.6 olurken Sabribey çeşidinden \%78.9 değeri ile ortalamaya yakın bir değer elde edilmiştir.

Ekstrakt farkı özelliği bakımından en düşük değer \%0.71 ile 21 nolu hat en yüksek \%4.66 ile 17 nolu hatta bulunurken Sabribey çeşidinde \%0.91 değeri elde edilmiştir (Çizelge 9). $\mathrm{Bu}$ denemede hartong sayısında \%38 ve kolbach sayısında \%70.7 ortalama elde edilmiştir. Sabribey çeşidi hartong sayısı bakımından deneme ortalamasında kolbach sayısı bakımından ise deneme ortalamasından daha yüksek değer göstermiştir. Enzim aktivitelerinin bir göstergesi olan Hartong sayısı bakımından 8 hat dışında tüm genotipler kabul edilebilir düzeydedir.
Her iki yılda elde edilen verim ve kalite analiz sonuçlarına göre 11 numaralı hattın (Sabribey çeşidi) tescil denemelerine alınması için 2016 yılında Ankara Tohumluk Tescil ve Sertifikasyon Merkezi Müdürlüğüne Geçit Kuşağı Tarımsal Araştırma Enstitüsü Müdürlüğü tarafından tescil başvurusu yapılmış çeşit adayı 2017 ve 2018 yıllarında tescil denemelerine alınmış ve 2019 yılında tescil komitesi tarafından oy birliği ile "Sabribey" ismi ile maltlık olarak tescil edilmiştir.

Kışa ve soğuğa dayanıklı olan Sabribey çeşidi hastalıklara dayanıklılık yönünden de iyi sonuçlar göstermiştir. Orta Anadolu ve Geçit Bölgesi Kuruda Arpa Tarımsal Değerleri Ölçme Denemelerinde bölgenin önemli hastalıklarından biri olan Arpa Çizgi Yaprak Lekesi (Pyrenophora graminea) hastalığına orta dayanıklı olarak belirlenmiştir. Ayrıca Toprak Kaynaklı Buğday Mozaik Virüsü (Soil Borne Wheat Mosaic Furovirus-SBWMV) hastalığına orta derecede dayanıklılık göstermektedir.

\section{SONUÇ}

Arpanın geniş alanlarda yetiştirildiği Orta Anadolu Bölgesi için maltlık kalitesi üstün olan yeni çeşitlerin üretim alanlarına hızla girmesi önem taşımaktadır. Böylece bu bölgelerde, çevre şartlarından daha az etkilenen, daha verimli ve üstün malt kalitesindeki yeni çeşitler sayesinde hem ülkemizin maltlık arpa ihtiyacı karşılanacak hem de birim alandan daha fazla verim dolayısı ile milli ekonomiye daha fazla katkı sağlanacaktır. Islah çalışmalarının en temel özelliği sürekli olmasıdır. Sabribey gibi yeni arpa çeşitleri üretime kazandırıldığında çalışma bitirilmemekte aksine daha verimli, maltık kalitesi daha iyi, olumsuz koşullar ile hastalık ve zararlılara daha dayanıklı çeşit geliştirme çalışmaları devam etmektedir. Bu çalışmanın verilerine dayalı olarak yapılacak melezlemeler ve o materyalde yapılacak seleksiyonlarla daha yüksek malt ekstraktına sahip genotiplerin seçilme potansiyeli oldukça yüksek gözükmektedir.

\section{KAYNAKLAR}

Anonim (2008) Geçit Kuşağı Tarımsal Araştırma Enstitüsü Müdürlüğü, İklim Kayıtları, Eskişehir.

Anonim (2020) http://www.eskisehirtarim.gov.tr. (Erişim tarihi: 10/02/2020)

Anonim (2020a) http://www.tmo.gov.tr/Upload/Document /hububatsektorraporu 2019.pdf (Erişim Tarihi: 16/02/2021).

Anonim (2020b) http://www.tuik.gov.tr/Ust Menu.do? metod=temelist (Erişim Tarihi: 15/01/2021).

Anonymous (1960) International Association of Creal Chem. ICC Standart No: 105

Anonymous (1986) Brauwelt Brevier 1986, 8500 Nümberg, p, 114-142

Akkaya A, Aktan \$̧ (1990) Erzurum Yöresinde Yetiştirilebilecek Yazlık Arpa Çeşitlerinin Belirlenmesi 
Üzerine Bir Araştırma. Atatürk Üniversitesi Zir. Fak. Dergisi, 21:9-27

Atlı A, Ozan A.N, Özkara R (1992) Arpada Yapılan Basit Analizlerle Malt Kalitesinin Tahmin Edilmesi Üzerine Araştırmalar. Arpa-Malt Semineri 25-27 Mayıs 1992, Konya.

Baik BK, Ullrich SE (2008) Barley for Food: Characteristics, Improvement, and Renewed Interest. Journal of Cereal Science, 48: 233-242.

Ceccarelli S, Grando S, Capettini F Baum M (2007) Barley Breeding for Sustainable Production. International Center for Agricultural Research in the Dry Areas (ICARDA), p 17 Aleppo, Syria.

Candan B (2009) Arpa, Malt ve Birada $\beta$-Glukan İçeriği ve Bira Kalitesi Üzerine Etkileri. Yüksek Lisans Tezi, Ege Üniversitesi Fen Bilimleri Enstitüsü, Gıda Mühendisliği Anabilim Dalı, İzmir.

Çekiç C, Savaşlı E, Dayığlu R, Önder O, Karaduman Y, Avcıoğlu R (2008) Ekmeklik Buğdayda (Triticum aestivum L.) Ekim Zamanı ve Sıklığı İle Kalite Kriterleri Arasındaki illişkilerin Belirlenmesi. Ülkesel Tahıl Sempozyumu, 2-5 Haziran 2008, Konya, 201-209.

Çelik S, Köksel H (1995) Arpa $\beta$-glukanlarının Fizikokimyasal Özellikleri, Teknolojik ve Besinsel Önemleri, Poster Bildiri, III. Arpa-Malt Semineri, Konya, 357.

Çölkesen M, Cesurer L, Yürürdurmaz C, Demirbağ V, Çiçek A, Başgül A, Engin A (1999) Kahramanmaraş Koşullarına Uygun Yüksek Verimli Arpa Çeşitlerinin Belirlenmesi. Türkiye III. Tarla Bitkileri Kongresi, 15-20 Kasım 1999, Cilt I, Genel ve Tahıllar, Adana, 234-239.

Ewertson, G (1977) Protein Content and Grain Quality Relation in: Barley Ph. D. Thesis. Agricultural College of Sweden, Uppsala.

Köten M, Ünsal S, Atlı A (2013) Arpanın İnsan Gıdası Olarak Değerlendirilmesi. Türk Tarım-Gıda Bilim ve Teknoloji Dergisi, 1, 51-55.

McCleary B.V, Codd R (1991) J. Of Science of Food and Agriculture. 55: 303-331.

Munns R, James RA, Läuchli A (2006) Approaches to Increasing the Salt Tolerance of Wheat and Other Cereals. Journal of Experimental Botany, Vol. 57, No: 5, pp. 1025-1043
Nasr HG, Shands HL, Forsberg RA 1973. Correlation Between Kernals Pulmpness, Lodging and Other Agronomic Characteristic in Six-Rowed Barley Crosses. Crop Sci. 13 (4): 399-401.

Öztürk I, Avcı R, Kahraman T (2007) Trakya Bölgesinde Yetiştirilen Bazı Arpa (Hordeum vulgare $L$ ) Çeşitlerinin Verim ve Verim Unsurları ile Bazı Kalite Özelliklerinin Belirlenmesi. U.Ü. Ziraat Fakültesi Dergisi, 21 (1): 5968.

Sayim I, Ergun N, Aydoğan S (2018) Kavuzsuz Arpa http://www.ankarahalkekmek.com.tr/Dosyalar/6280 5911779.pdf. (Erişim Tarihi: 20/11/2018).

Smith BD, Nesbitt M (1995) The Emergence of Agriculture (p. 231). New York: Scient. American Library.

Sönmez AC, Olgun M, Yüksel S, Belen S, Yıldırım Y, Çakmak M, Karaduman Y, Akın A, Önder O (2020) Arpa (Hordeum vulgare L.) Islah Materyalinin Bazı Maltlık Kalite Özellikleri ile Bu Özellikler Arası İlişkilerin Belirlenmesi. Black Sea Journal of Agriculture 3(2): 155-161.

Sparrow D.H.B (1970) Some Genetical Aspects of Malting Quality in Barley Genetics II, 559-574. Pullman, Washington.

Şehirali S, Özgen M (2007) Bitki Islahı. Ankara Üniversitesi, Ziraat Fakültesi Yayınları Yayın No: 1553, Ders Kitabı: 506, Ankara, s:90-91

Tosun H (1993) 8 Adet Tescilli Arpa Çeşitlerinin Genotip x Çevre Intereksiyonları. (Doktora tezi) Selçuk Üniversitesi Ziraat Fakültesi Fen Bilimleri Enstitüsü Müdürlüğü (Yayımlanmamış).

Türker i (1977) Malt-Bira Kimyası ve Teknolojisi. Ankara Üniversitesi Ziraat Fakültesi Yayınları, No: 660. Ankara.

Uluöz M (1965) Buğday, Un ve Ekmek Analizleri. E.Ü.Z.F. Yayınları. No:57 E.Ü. Matbaası. İzmir.

Williams P, El-Haramein F.J, Nakkoul H, Rihawi S (1986) Crop Quality Evaluation Methods and Guidelines, ICARDA.

Yazıcıoğlu T, Geçkiner G, Kılıç O (1976) Biralık Güdümlü Arpa Projesi. Proje No: TOAG/125 TÜBITAK, Tarım ve Ormancılık Araştırma Grubu, Gebze. 